\title{
THE IMPLEMENTATION OF THE RIGHT TO EDUCATION IN SOUTH AFRICA AND NIGERIA (PART 2)
}

\author{
Elijah Adewale Taiwo \\ LLB LLM MPhil BL LLD \\ Professor, College of Law, Afe Babalola University \\ Ado-Ekiti, Ekiti State, Nigeria \\ Research Associate, Faculty of Law \\ Nelson Mandela Metropolitan University \\ Port Elizabeth \\ Avinash Govindjee \\ BA LLB LLM (Cum Laude) LLD \\ Professor of Law, Faculty of Law \\ Nelson Mandela Metropolitan University \\ Port Elizabeth \\ Attorney of the High Court of South Africa
}

\section{SUMMARY}

This is the concluding part of the two articles dealing with the implementation of the right to education in South Africa and Nigeria. While the first article examines legislative measures put in place towards implementing the right to education, this follow-up article examines the non-legislative measures, that is, administrative and other measures. The article also identifies some problems such as inadequate planning, poor implementation of policies, inadequate resources and commitments as the prime factors hampering the effective implementation of the right to education in the two countries. It concludes by submitting that solving these problems and making the right to an education realizable call for a renewed government commitment and investment of appropriate human and financial resources on education.

\section{INTRODUCTION}

This is the concluding part of the two articles dealing with the implementation of the right to education in South Africa and Nigeria. In the first article, the nature and the content of the states' obligations with regards to the right to education were examined. It also examined the implementation measures put in place towards implementing the right to education in South Africa and 
Nigeria. The article examined only the legislative measures while other measures of implementation, such as, administrative, judicial, quasi-judicial measures as well as international measures are the focus of this concluding article. The article also identifies some problems hampering the effective implementation of the right to education in the two countries. It concludes by submitting that solving these problems and making the right to education a government priority, coupled with appropriate human and financial investment of resources is warranted. The article therefore suggests some recommendations with regard to how to ensure an effective implementation of this right in the two countries.

\section{MEASURES OF IMPLEMENTATION: NON- LEGISLATIVE MEASURES}

By requiring states parties to use "all appropriate means", the International Covenant on Economic, Social and Cultural Rights (ICESCR), 1966 adopts a broad and flexible approach which enables the particularities of the legal and administrative systems of each state, as well as other relevant considerations, to be taken into account. ${ }^{1}$ There are several non-legislative measures such as the provision of judicial or other effective remedies, administrative, financial, educational and social measures that are regarded as "appropriate means". "As noted earlier in the previous part, the transformation of economic, social and cultural rights into positive law, whether in a national constitution or in legislation is not enough. Instead, the rights must be translated into realities so that they are realized in fact and this requires comprehensive administrative measures and social action. ${ }^{3}$ Including these, other measures of implementing the right to education will now be considered, with administrative measures coming first.

\section{Administrative measures}

Administrative measures are recognized as one form of "appropriate measures" mentioned in article 2 of the ICESCR and article 4 of the Convention on the Rights of the Child (CRC), 1989 towards implementing the right to education. ${ }^{4}$ The responsibility for ensuring the conditions and specific resources for implementing human rights within each state lies primarily with the executive and its organs, which operate in the framework of government and various government departments. ${ }^{5}$ The executive and state administration, through adoption of policies or through executive or

CESCR General Comment 9: Domestic Application of the Covenant, 1998 par 1.

2 CESCR General Comment No. 3 on the Nature of States Parties Obligations 1990 (UN Doc. HRI/GEN/1/Rev.5, 2001) par 5 and 7.

3 See Eide "Economic, Social and Cultural Rights as Human Rights" in Eide, Krause and Rosas (eds) Economic, Social and Cultural Rights: A Textbook 2ed (2001) 17; and see also General Comment 9 par 2.

4 See CESCR General Comment 3 par 7; CRC Committee, General Comment No. 5: General Measures of Implementation of the Convention on the Rights of the Child (UN Doc. CRC/GC/2003/5, 2003) par 26-27.

5 Marie "National Systems for the Protection of Human Rights" in Symonides (ed) Human Rights: International Protection, Monitoring, Enforcement (2003) 257262. 
administrative decisions, often interpret socio-economic rights and define the duties imposed on them. ${ }^{6}$ The executive has the task of applying or implementing at the national level the laws adopted by Parliament and it must act with due respect for constitutional principles and norms. It is also responsible for fulfilling the human rights commitments undertaken on behalf of a state and to report to the appropriate international bodies when the relevant instruments so require. ${ }^{7}$ This makes the executive the central machinery for the effective observance of human rights at the national level. ${ }^{8}$

In terms of section 7(2) of the Constitution of the Republic of South Africa, 1996, government is enjoined to "respect, protect, promote and fulfil the rights in the Bill of Rights", and in this case, the right to education guaranteed in section 29 of the Constitution. The implication here is that the State must not only refrain from interfering with the enjoyment of the right to education, but must also act so as to protect, enhance and realize its enjoyment. ${ }^{9}$ The state may do this not only through the legislature by enacting the relevant laws, but in addition, it is required to do this by formulating policies and making appropriate administrative decisions. ${ }^{10}$ The policy formulation or administrative decisions in this sense will translate these rights into enforceable legal entitlements. ${ }^{11}$ In terms of policy formulation, the South African government, through the Department of Education, has done well; it has issued several White Papers on transformation of education in the country. The value and principles which "drive the national policy" in education and training are set out in the 1995 White Paper on Education which re-affirms that education and training are basic human rights and imposes an obligation on the state to advance and protect. $^{12}$

Further, in terms of this White Paper, the state's obligation includes the duty to provide "advice and counselling" in respect of people "fragmented by such factors as past unjust laws, migratory labour practices, and marital breakdown, and handicapped by illiteracy", together with "appropriate care and educational services for parents, especially mothers, and young children within the community". ${ }^{13}$ The principle also reaffirms the commitment to

6 Brand "Introduction to Socio-economic Rights in the South African Constitutions" in Brand and Heyns (eds) Socio-Economic Rights in South Africa (2005) 1-56 16.

7 Marie "National Systems for the Protection of Human Rights" in Human Rights: International Protection, Monitoring, Enforcement 262.

8 Marie "National Systems for the Protection of Human Rights" in Human Rights: International Protection, Monitoring, Enforcement 262-263.

9 See Brand "Introduction to Socio-economic Rights in the South African Constitution" in Socio-economic Rights in South Africa 9; see also Liebenberg "Reflections on Drafting a Bill of Rights: A South African Perspective" in Kersting (ed) Constitution in Transition: Academic Inputs for a New Constitution in Zimbabwe (2009) 4-5; and The Social and Economic Rights Action Centre (SERAC) and the Centre for Economic, Social and Cultural Rights v Nigeria, Communication n. 155/96 (2001) AHRLR 51 (ACHPR 2001) par 44-48.

10 Mubangizi "The Constitutional Protection of Socio-Economic Rights in Selected African Countries: A Comparative Evaluation" (2006) 2(1) African Journal of Legal Studies $15-6$.

11 Brand "Introduction to Socio-economic Rights in the South African Constitutions" in SocioEconomic Rights in South Africa 16.

12 White Paper on Education and Training in a Democratic South Africa: First Steps to Develop a New System, GG 357 (16312) (1995) 21.

13 White Paper on Education and Training in a Democratic South Africa, 1995 par 5. 
provide access to lifelong learning, education and training of good quality. In making these commitments, the White Paper also commits itself to redress of educational inequalities among those sections of people who have suffered particular disadvantages; the principle of equity; rehabilitation of schools and colleges; the idea of democratic governance in all levels of the system; restoration of the culture of teaching, learning and management involving the creation of a culture of accountability; sustainability and productivity. ${ }^{14}$

On the issue of non-discrimination in education, the Education White Paper 6 on Special Needs Education, Building an Inclusive and Training System 2001, strengthens the government policy on education without discrimination. ${ }^{15}$ The White Paper provides a framework for a single inclusive system of education and training in South Africa. It outlines what an inclusive education and training system is, and how it should be built. ${ }^{16}$ The White Paper declares the commitment of the government to the provision of educational opportunities, especially for those learners who experience barriers to learning or who have dropped out of learning, because of the inability of the education and training service to accommodate their learning needs. It also outlines how the education and training system must transform itself to assist in building and securing a caring and humane society. ${ }^{17}$

Like South Africa, the Nigerian government has equally formulated policies towards implementing the right to education in the country. The government policy on education is spelt out in the 2004 National Policy on Education. The Policy sets out inter alia that government shall take various measures to implement the policy and goals set out. This Policy states that education should be highly rated in the national development plans because education is the most important instrument of change. Any fundamental change in the intellectual and social outlook of any society has to be preceded by an educational revolution. ${ }^{18}$ It states that life-long education shall be the basis of the nation's educational policy $;^{19}$ education and training facilities shall continue to be expanded in response to societal needs and be made progressively accessible to afford the individual a far more diversified

4 White Paper on Education and Training in a Democratic South Africa 21-22.

15 See also, the White Paper on Further Education and Training, 1998 which provides for the framework for further education and training and aims at pursuing government's constitutional obligations on education. The document outlines government's vision and policy framework for a nationally coordinated system of Further Education and Training (FET). The White Paper ensures access to high quality education and training; it offers a wide range of learning options to a diverse range of learners, including school-going young people, out-of-school youth, young adults and the larger adult population. See the White Paper on Further Education and Training: Preparing for the Twenty-first Century through Education, Training and Work, Department of Education, Pretoria (1998) 6.

16 See Williams Inclusive Education: A Model for In-Service Teachers (DEd thesis) Nelson Mandela Metropolitan University (2007) 40.

17 See Department of Education, Education White Paper 6 on Special Needs Education, Building an Inclusive and Training System (2001) 20.

18 Par 9(a) of the Policy.

19 Par 9(b) of the Policy. 
and flexible choice $;^{20}$ and that educational activities will centre on the learner for maximum self-development and self-fulfilment. ${ }^{21}$

The Policy further states that universal basic education, in a variety of forms depending on needs and possibilities, should be provided for all citizens and that effort should be made to relate education to overall community needs. ${ }^{22}$ The Policy also states that educational assessment and evolution should be liberalized by their being based in whole or in part on continuous assessments of the progress of the individual. ${ }^{23}$ It requires that modern educational techniques should be used increasingly and improved upon at all levels of the education system; ${ }^{24}$ that the education system should be structured to develop the practice of self-learning. ${ }^{25}$ It states further that opportunity should continue to be made for religious instruction; and that no child should be forced to accept any religious instruction which is contrary to the wishes of his or her parents. ${ }^{26}$ It also provides that physical and health education are to be emphasized at all levels of the education system. ${ }^{27}$ Also, the Roadmap for Nigerian Education Sector released in 2009 constitutes the government's latest policy on education. It identifies the major problems facing Nigerian education and the ways of solving them. ${ }^{28}$ The Roadmap is proactive and looks into the future; it strengthens government policy on free, compulsory and universal basic education among others.

Administrative measures in terms of policy formulation in South Africa and Nigeria are encouraging considering that there are ample government policies ensuring equal access to education. It is submitted, however, that governments in both countries need to do more by implementing and monitoring those policies effectively. An issue that needs to be emphasized is that unlike the position in South Africa, the Nigerian government is yet to develop a clear-cut policy on inclusive education for persons with disabilities. In Nigeria, learners with disabilities are often neglected and discriminated against in terms of education, health, and social facilities. The few schools available for this category of people in the country are often in a state of neglect and are not properly maintained. This is a violation of Nigeria's obligation in terms of the ICESCR to provide education for all without discrimination. The adoption of an inclusive education policy, as per the South African experience will help the Nigerian government to guarantee adequately the right of learners with disabilities, thereby ensuring equal treatment.

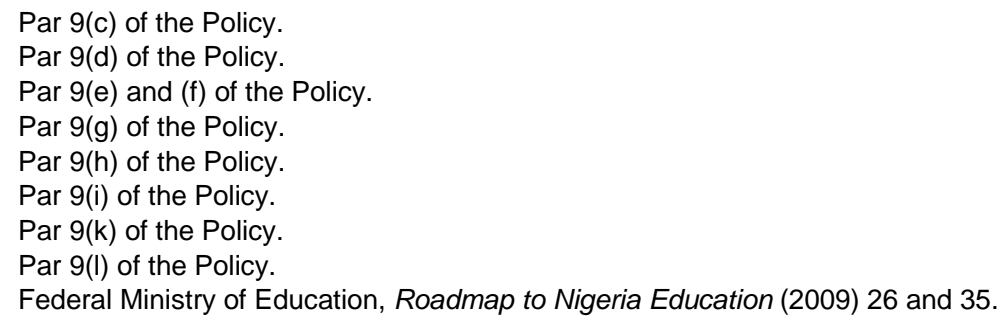




\section{Judicial and Quasi-Judicial Measures}

According to the CESCR, among the measures which are considered appropriate, in addition to legislation, is the provision of judicial remedies with respect to rights which may, in accordance with the national legal system, be considered justiciable. ${ }^{29}$ The Committee notes further "that the enjoyment of the rights recognised, without discrimination, will often be appropriately promoted, in part, through the provision of judicial or other effective remedies ..., ${ }^{30}$ Thus, in this section, the implementation of the right to education through judicial and quasi-judicial measures is examined. The judicial measure is the avenue through the court while quasi-judicial measures are the implementation through entities such as human rights' commissions. Although there are other institutions established under both the South African and Nigerian Constitutions for the protection of human rights, ${ }^{31}$ given their limited impact on the realization of the right to education, the discussion in this section will be limited to the two institutions mentioned above.

\section{Courts of law}

In the absence of an independent, courageous and vigorous judiciary, a Bill of Rights cannot fulfil its objectives. Its transformative potential will remain unrealized..$^{22}$ Courts may protect socio-economic rights, and in this case, the right to education, in two ways. Firstly, through their law-making powers of interpreting legislation and developing the rules of the common law and, secondly, by adjudicating constitutional and other challenges to state measures that are intended to advance those rights. ${ }^{33}$ Once human rights have been recognized in the constitution and laid down in legislation, their observance and guarantee make it necessary to provide remedies in the event of their violation. ${ }^{34}$ It is the judiciary that ensures that everyone has the right to an effective remedy for acts violating the fundamental rights granted by the constitution or by law. ${ }^{35}$ Failure to implement relevant legislation and disputes about the content of statutory provisions effectively introduces the role of the national judiciary. Even if rights are relatively clearly formulated, disputes about their content may still arise. Activist courts may, therefore,

General Comment 3 par 5.

lbid.

31 See s 181 of the Constitution of the Republic of South Africa, 1996 which establishes the Public Protector, the Commission for the Promotion and Protection of Rights of Cultural, Religious and Linguistic Communities, the Commission for Gender Equality among others. See also s $315(5)(b)$ of the Constitution of the Federal Republic of Nigeria, 1999 which recognizes and validates the Public Complaints Commission.

32 See Liebenberg "Reflections on Drafting a Bill of Rights: A South African Perspective" in Constitution in Transition: Academic Inputs for a new Constitution in Zimbabwe 1.

33 See Brand "Introduction to Socio-economic Rights in the South African Constitution" in Socio-economic Rights in South Africa 38-39.

34 Marie "National Systems for the Protection of Human Rights" in Human Rights: International Protection, Monitoring, Enforcement 261.

35 Ibid; and see also The Federal Republic of Nigeria v Ifegwu [2003] 15 NWLR (pt 842) 113 184 (SC). 
use constitutional provisions to invigorate impasses about the implementation of social and economic rights. ${ }^{36}$

Section 8(3)(a) of the South African Constitution provides that, when applying the Bill of Rights to a natural or juristic person, a court in order to give effect to a right in the Bill, must apply or develop the common law to the extent that legislation does not give effect to that right. ${ }^{37}$ The South African Constitution also obliges a court or tribunal to promote the values that underlie an open and democratic society based on human dignity, equality and freedom. The courts are also obliged to consider international law and may also consider foreign law. ${ }^{38}$ A significant number of cases involving socio-economic rights generally have come before the South African courts. $^{39}$ These cases have been hailed as torch-bearers to the judicial enforcement of socio-economic rights. ${ }^{40}$ South Africa is one of the few countries in the world whose highest court treats socio-economic rights with

${ }^{36}$ See Viljoen "The Justiciability of Socio-economic and Cultural Rights: Experience and Problems" in Donders and Volodin (eds) Human Rights in Education, Science and Culture (Legal Developments and Challenges) (2007) 58.

37 See also s 39(2) of the Constitution. However, the court may also develop rules of common law to limit the right accordance with limitation in s 36(1) of the Constitution. See s 8(3)(b) of the Constitution.

38 See s 39(1)(a)-(c) of the Constitution.

39 See Government of the Republic of South Africa v Grootboom 2001 (1) SA 46 (CC), in this case, a group of adults and children had been rendered homeless as a result of eviction from their informal dwellings situated on private land ear-marked for low-cost housing. They applied for an order directing the local government to provide them with temporary shelter, adequate basic nutrition, health care and other social services. The Constitutional Court held that the state had failed to meet the obligations placed on it by s 26 and therefore declared that the state's housing programmes were inconsistent with $s 26(1)$ of the Constitution. See also, Minister of Health v Treatment Action Campaign 2002 (5) SA 703 (CC). In the Treatment Action Campaign case, the TAC, a non-governmental organization, in a bid to force government to provide anti-retroviral drug that could reduce by half the rate of HIV transmission from mothers to babies, be freely distributed to women infected with HIV. The Constitutional Court held that the government's policy and measures to prevent mother-tochild transmission of HIV at birth fell short of compliance with s 27(1) and (2) of the Constitution. It ordered the state to provide the required medication and remedy its programme. This case can be contrasted with an earlier decision of the same court in Soobramoney v Minister of Health, KwaZulu-Natal 1998 (1) SA 765 (CC); 1997 (12) BCLR 1696. This case involved an application for an order directing a state hospital to provide the appellant with ongoing dialysis treatment and interdicting the respondent from refusing him admission to the renal unit. The Constitutional Court held that the applicant could not succeed in his claim and found that the denial of the required treatment did not breach the provision of $s$ 27(1) of the Constitution which guarantees the right of everyone to have access to health-care services, and s 27(3) on the right to emergency medical treatment. Another case is Khosa v Minister of Social Development 2004 (6) SA 505 (CC). In Khosa, legislation that excluded permanent residents and their children from access to social assistance was successfully challenged and found to be inconsistent with s 27(1) and 9(3) of the Constitution which guarantees everyone the right of access to social security and assistance and prohibits unfair discrimination respectively. Other cases in this respect include, Bav Biljon v Minister of Correctional Services 1997 (4) SA 441; 1997 (6) BCLR 789 (C); Resident of Bon Vista Mansion v Southern Metropolitan Local Council 2002 (6) BCLR 625 (W); Port Elizabeth Municipality v Various Occupiers 2004 (12) BCLR 1268 (CC); Van Rooyen v Stoltz 2005 (1) BCLR 78 (CC); and Minister of Public Works v Kyalami Ridge Environmental Association 2001 (3) SA 1151 (CC).

40 Mubangizi 2006 2(1) African Journal of Legal Studies 1-19 and 6. 
the same reverence as civil and political rights. ${ }^{41}$ In the process of adjudication, the courts have helped in giving meaning and content to socioeconomic rights guaranteed in the South African Constitution and thereby assisted in advancing the process of implementation.

Unlike the South African courts, the Nigerian courts have not articulated so much on the socio-economic rights and the right to education in particular. In a number of cases coming before the courts on this issue, the issue of non-justiciability has often been raised. ${ }^{42}$ Most of the rights constituting socio-economic and cultural rights are categorized under the Nigerian Constitution as fundamental objectives and directive principles of the state policies, which in terms of section 6(6)(c) of the Nigeria Constitution, are non-justiciable. ${ }^{43}$ It is submitted that the expansive interpretation approach of the Indian judiciary is necessary to invigorate the right to education from a non-justiciable right to a justiciable right in Nigeria. The Indian experience demonstrates that directive principles may, in practice, become justiciable. ${ }^{44}$ Also in this regard, providing for this right as a justiciable right in the Constitution, as has been the case in South Africa, will be of immense benefit to Nigeria.

The recent judgment of the ECOWAS Court in Registered Trustees of the Socio-Economic Rights \& Accountability Project (SERAP) v Federal Republic of Nigeria \& Universal Basic Education Commission ${ }^{45}$ leans toward the direction of an expansive interpretation. In that case, the court held that in terms of article 17 of the African Charter on Human and Peoples' Rights, 1981 every Nigerian has the right to education. In the current climate, where economic and social rights are not deemed legally enforceable in Nigerian courts and where victims of violations of these human rights are denied access to an effective remedy, this unanimous judgment of the ECOWAS Court of Justice is a welcome landmark. It reaffirms that states are obliged to promote and ensure the universality and indivisibility of all human rights as recognized by the African Charter on Human and Peoples' Rights.

A final and crucial aspect of the implementation of the socio-economic rights by the court is the kind of remedies which a court may provide for

41 See Kende Constitutional Rights in Two Worlds: South Africa and the United States (2009) 262.

42 See Archbishop Anthony Olubunmi Okogie v Attorney General of Lagos State (1981) 1 NCLR 218; see also, Olowu "Human Rights and the Avoidance of Domestic Implementation: The Phenomenon of Non-Justiciable Constitutional Guarantees" 2006 69(1) Saskatchewan $L R$ 39-78 56-60; and Olowu "The Right to Social Security in Nigeria: Taking Up the Gauntlet" 2007 1(2) CALS Review of Nigerian Law and Practice 91101.

43 See Uzoukwu v Ezeonu II [1991] 6 NWLR (pt 200) 708 761-762, where the Court of Appeal observed as follows: "There are other rights which may pertain to a person which are neither fundamental nor justiciable in the court. These may include rights given by the Constitution as under the Fundamental Objectives and Directive Principles of State Policy under Chapter 2 of the Constitution."

44 The Indian Supreme Court held in Unni Kkrishnan v State of Andhra Pradesh (1993) 1 SCC 645 , that the Directive Principles that compulsory education should be provided to children up to the age of 14 years had matured into a fundamental right.

45 Suit No: ECW/CCJ/App/12/07; Judgement No: ECW/CCJ/JUD/07/10, delivered at Abuja, Nigeria on 30/11/2010) par 26; and see also the earlier ruling of the same court in the same suit involving the same parties (Suit No: ECW/CCJ/App/0808, delivered at Abuja, Nigeria on 27/10/2009), par 17. 
violations of these rights. As has previously been argued, once human rights have been recognised in the constitution and laid down in legislation, their observance and guarantee make it necessary to provide remedies in the event of their violation. ${ }^{46} \mathrm{~A}$ remedy in this sense is an order made by a court in response to a proved violation of a person's rights. ${ }^{47}$ Ensuring an effective remedy is an integral part of the implementation of any human rights. ${ }^{48}$ It is the judiciary that ensures that everyone has the right to an effective remedy for an act violating the fundamental rights granted by the Constitution or by law. 49

In terms of the South African Constitution, the courts may declare that any law or conduct that is inconsistent with the Constitution is invalid to the extent of its inconsistency. ${ }^{50}$ In addition, they enjoy broad powers to "make any order that is just and equitable. ${ }^{.51}$ Such orders include a suspended declaration of invalidity for a period and on any conditions to allow the competent authority to correct the defect; ${ }^{52}$ a declaration of rights; ${ }^{53}$ prohibitory or mandatory orders; exercising a supervisory jurisdiction, judicial review; ${ }^{.4}$ and compensation (or constitutional damages). In the absence of a broad array of remedial tools such as those listed above, it may be impossible to achieve the constitutional objectives.

\section{National human-rights bodies}

Specialized human-rights institutions perform a complementary function to the traditional institutions such as the legislature, the executive and the

46 Marie "National Systems for the Protection of Human Rights" in Human Rights: International Protection, Monitoring, Enforcement 261.

47 See Mbazira You Are the "Weakest Link" in Realizing Socio-Economic Rights: Goodbye Strategies for Effective Implementation of Court Orders in South Africa (2008) 3-4.

48 Rishmawi A Commentary on the United Nations Convention on the Rights of the Child: Article 4 - Nature of States Parties' Obligations (2006) 49; and see also CRC Committee General Comment No. 5 on General Measures of Implementation of the Convention on the Rights of the Child (UN Doc. CRC/GC/2003/5, 2003) par 24.

49 Marie "National Systems for the Protection of Human Rights" in Human Rights: International Protection, Monitoring, Enforcement 261.

50 See s 172(1)(a) of the South African Constitution; $s$ and 6 of the Nigerian Constitution.

51 See s 172(1)(b) of the South African Constitution and s 6(6)(a) of the Nigerian Constitution which vests in the courts all the inherent powers and sanctions of a court of law. In Fose $v$ Minister of Safety and Security 1997 (3) SA 786 (CC) par [19], the court held: "Appropriate relief will in essence be relief that is required to protect and enforce the Constitution. Depending on the circumstances of each particular case the relief may be a declaration of rights, an interdict, a mandamus or such other relief as may be required to ensure that the rights enshrined in the Constitution are protected and enforced. If it is necessary to do so, the courts may even have to fashion new remedies to secure the protection and enforcement of these all important rights." See also Mohamed $v$ President of RSA 2001 (3) Sa 893 (CC), par [71]; City of Cape Town v Rudolph [2003] 3 All SA 517 (C); and Pretoria City Council v Walker 1998 (2) 363 (CC) par [96].

52 See s 172(b)(ii) of the 1996 South African Constitution and s 6(6)(a) of the 1999 Nigerian Constitution.

53 See s 38(1) of the 1996 South African Constitution and s 6(6)(a) of the 1999 Nigerian Constitution.

54 Saharay The Constitution of India: An Analytical Approach 3ed (2002) 672. 
judiciary. ${ }^{55}$ The idea that each state should set up bodies specifically concerned with the progress and observance of human rights on its territory is not recent. It coincides with the introduction at international level of the early institutions for the promotion and protection of human rights worldwide. ${ }^{56}$ In order to protect constitutional democracy and enhance the implementation of human rights, both the South African and Nigerian Constitutions provide for the establishment of the national human rights commissions. In addition to these commissions, the two Constitutions also establish other similar human-rights institutions.

The South African Constitution, for instance, established the South African Human Rights Commission (SAHRC) and assigned to it a mandate to promote, monitor and assess the observance of human rights in South Africa. ${ }^{58}$ The main functions of the Commission are to promote respect for human rights and a culture of human rights and to monitor and assess the observance of human rights in South Africa. ${ }^{59}$ In the context of socioeconomic rights, the South African Constitution obliges relevant organs of the state to provide the Commission with information on the measures they have taken towards the realization of those rights on a regular basis. ${ }^{60}$ In order to fulfil this mandate, the Commission has developed a series of reporting protocols, which has been periodically revised. The Commission has used the data collected along with supplementary information to write detailed reports on the status of the realization of human rights in the country.

In this direction, in the much-cited case of Government of the Republic of South Africa $v$ Grootboom, the Constitutional Court appointed the SAHRC to monitor the implementation of its order that the state should devise and implement a housing programme that would cater for people in a situation of

55 Marie "National Systems for the Protection of Human Rights" in Human Rights: International Protection, Monitoring, Enforcement 264.

56 Marie "National Systems for the Protection of Human Rights" in Human Rights: International Protection, Monitoring, Enforcement 268.

57 In Nigeria for instance, there is the Public Complaint Commission while in South Africa, there is the Office of the Public Protector. The Office of the Public Protector plays a more indirect but important role in the enforcement of human rights in South Africa. In terms of $s$ 182(1)(a) of the Constitution, the Office of the Public Protector is to perform threefold functions namely, to investigate any improper conduct in state affairs or public administration; to report such conduct; and to take appropriate remedial action. It is submitted that in performing these functions, the Public Protector not only curbs humanrights abuses resulting from state misconduct and public maladministration but also protects and enforces constitutional rights including socio-economic rights. See Mubangizi 2006 2(1) African Journal of Legal Studies 7-8.

58 See s 181(1)(b) of the 1996 South African Constitution.

59 See $\mathrm{s} 184$ of the Constitution.

60 See s 184(3) of the Constitution which provides: "[e]ach year, the Human Rights Commission must require relevant organs of state to provide the Commission with information on the measures that they have taken towards the realization of the rights in the Bill of Rights concerning housing, health care, food, water, social security, education and the environment".

61 See Chapman "Development of Indicators for Economic, Social and Cultural Rights: The Rights to Education, Participation in Cultural Life and Access to the Benefits of Science" in Donders and Volodin (eds) Human Rights in Education, Science and Culture (Legal Developments and Challenges) (2007) 127. 
homelessness. ${ }^{62}$ In this way, the Commission plays an active role in implementing the order of the court on socio-economic rights. However, the Commission has been criticized on account of lack of guidelines regarding what exactly should be monitored and timeframes for feedback. ${ }^{63}$ According to Pillay, the SAHRC should only be used in supervisory interdicts where the court retains jurisdiction over a matter and can place strict time frames on the monitoring and reporting activity to be undertaken by the Commission. ${ }^{64}$

It is submitted that the SAHRC is one of the effective means through which the right to education can be implemented. On the issue that costs of education make schooling inaccessible to poor learners, the Commission conducted a public hearing on the right to basic education and observed that transport and uniform costs are often more of a burden on parents than school fees. ${ }^{65}$ The Report suggested some recommendations on improving accessibility of learners to education which include abolition of school fees at primary-school level; and that government should move rapidly to increase the number of fee-free schools available for poor learners; and that poor learners who live far from their nearest schools should receive statetransport assistance. ${ }^{66}$ In line with these recommendations, while statetransport assistance is not yet in place, government has consistently over the years increased the number of "no-fee schools" in the country.

Similarly, in Nigeria, the National Human Rights Commission Act established the National Human Rights Commission. ${ }^{67}$ The Commission was established for the protection of human rights, dignity and freedom. In terms of section 5 of the Act, the Commission shall deal with all matters relating to the protection of human rights as guaranteed by the Nigerian Constitution, the ACHPR, UDHR and other international treaties on human rights to which Nigeria is a signatory. Although the Commission has concentrated on the violation of the civil and political rights at the expense of the socio-economic and cultural rights, the multi-faceted functions of the Commission suggest that it is capable of assisting in the implementation of the socio-economic and cultural rights which include the right to education. No visible impact has

62 Similarly, in August v Electoral Commission 1999 (3) BCLR 1 (CC) par 42, the court ordered the government to marshal its resources to protect a prisoner's right to vote and went on to ensure the effective implementation of its order. The court gave clear directions for the implementation of its order to the Electoral Commission. The SAHRC was ordered to make arrangements for the prisoners to register and once registered to vote in the elections. The SAHRC was also required to furnish an affidavit setting out the manner in which the order would be complied with and to serve a copy on the attorneys for the applicants and on the Registrar of the Constitutional Court. A period of two weeks was given for the SAHRC to prepare the affidavit.

63 See Govindjee The Constitutional Rights to Social Assistance as a Framework for Social Policy in South Africa: Lessons from India (LLD thesis) Nelson Mandela Metropolitan University (2005) 96; see also, Ntlama "Unlocking the Future: Monitoring Court Orders in Respect of Socio-economic Rights" 2003 Paper written for the Constitutional Law and Legal Theory Conference at the University of Western Cape 8, cited in Govindjee The Constitutional Rights to Social Assistance 96.

64 Pillay "Implementation of Grootboom: Implications for the Enforcement of Socio-economic Rights" 2002 6(2) Law, Democracy \& Development 255274.

65 See South African Human Rights Commission Report of the Public Hearing on the Right to Basic Education (2006) par 39-40.

66 Ibid.

67 See s 1 of the National Human Rights Commission Act Cap N46, LFN 2004. 
yet been made by the Commission on socio-economic and cultural rights, perhaps due to the non-justiciability of these rights in Nigeria. ${ }^{68}$ However, the existence of this body gives enough succour to the view that at any time, the Commission could play a complementary role to the courts in protecting socio-economic and cultural rights and the right to education in particular.

\section{INTERNATIONAL MEASURES OF IMPLEMENTA- TION}

Apart from the obligation put on the states parties on the implementation of the socio-economic and cultural rights considered above, additional measures have been put in place at the international level. As international concern for the promotion and protection of human rights around the world has increased, different strategies have been developed to ensure compliance with international norms. The most basic of all of these procedures are that of state reporting-system and the practice of appointment of special rapporteurs. ${ }^{69}$

As noted earlier, the obligations in terms of the ICESCR are binding on every state party ${ }^{70}$ and, as such, every state must ensure that the measures adopted are reasonable, effective and produce results compatible with the Covenant. ${ }^{71}$ Although the Covenant gives each state party a measure of discretion to decide for itself which means are the most "appropriate" for implementing a particular right, the ultimate determination as to whether "all appropriate" measures have been taken is subject to the CESCR's review. ${ }^{72}$ It is in this context that states' reports are required to indicate the basis upon which the steps taken may be considered to be "appropriate". ${ }^{73}$ It should be noted, however, that the measures put in place at the international level are in the forms of supervisory mechanisms.

\section{State reporting-system}

At the global level, state reporting is one of the main supervisory mechanisms provided by the major UN human-rights treaties. ${ }^{74}$ It should be

${ }^{68}$ See s 6(6)(c) of the 1999 Nigerian Constitution.

69 Evans and Murray "The State Reporting Mechanism of the African Charter" in Evans and Murray (eds) African Charter on Human and People's Rights - The System in Practice, 1986-2006 2ed (2008) 49 50; and see also, Evans, Ige and Murray "The Reporting Mechanism of the African Charter on Human and Peoples' Rights" in Evans and Murray (eds) African Charter on Human and People's Rights - The System in Practice, 1986-2000 (2002) 3637.

70 See art 2 of the ICESCR in particular.

71 See Sepulveda The Nature of the Obligations under the International Covenant on Economic, Social and Cultural Rights (2003) 337-338.

72 General Comment 3 par 4.

73 Ibid.

74 See Olowu An Integrative Right-Based Approach to Human Development in Africa (2009) 34-37; and see also Mugwanya Human Rights in Africa: Enhancing Human Rights Through the African Regional Human Rights System (2003) 152. See in this regard, arts 9 (CERD), 40 (ICCPR), 21 (CEDAW), 19 (CAT), 16(1) (ICESCR) and 43(1) (CRC). This procedure is also employed at the regional level. For instance, art 62 of the African Charter provides: "[e]ach State Party shall undertake to submit every two years, from the date the present 
noted that the fact that the rights protected under the ICESCR require positive implementation in accordance with the availability of resources renders them less capable of judicial determination. ${ }^{75}$ For this reason, no provision was made for inter-state claims or individual complaints, as with the ICCPR, until December 2008 when the General Assembly unanimously adopted the Optional Protocol to the ICESCR. Instead, a supervisory body, that is, the CESCR, receives national reports. ${ }^{76}$ Prior to this time, the national reports constituted the only method of "enforcement" under the ICESCR. ${ }^{77}$ Like the CESCR, the CRC Committee also adopts the procedure of states reporting-system. ${ }^{78}$ States parties are obliged to report to the CRC Committee on measures they have taken to give effect to all the rights contained in the Convention.

Articles 16 and 17 of the ICESCR require states to submit reports, at intervals defined by the United Nations' Economic and Social Council (ECOSOC), on the measures which they have adopted and the progress made in achieving the observance of the rights in the Covenant. Reports should be made in accordance with the reporting guidelines, and the compliance of states with their obligations under the Covenant is monitored by the CESCR. ${ }^{80}$ The state reporting-system in international human-rights procedures aims to achieve multiple objectives including initial review by the implementing or oversight institution by which it is apprised of relevant domestic laws, content, practice and problems; monitoring with a view to addressing systematically associated problems of implementing and compliance; policy formulation which may help a state party improve its compliance with treaty obligations through appropriate adjustments in domestic policy; ensuring public scrutiny and accountability to both national and international constituencies; benchmarking and evaluation over time of

Charter comes into force, a report on the legislative measures taken with a view to giving effect to the rights and freedoms recognised and guaranteed by the present Charter". See also, Evans, Ige and Murray "The Reporting Mechanism of the African Charter on Human and Peoples' Rights" in African Charter on Human and People's Rights - The System in Practice, 1986-2000 36.

75 Dugard "International Human Rights" in Van Wyk, Dugard, De Villiers and Davis (eds) Rights and Constitutionalism: The New South African Legal Order (1994) 171177.

76 Dugard "International Human Rights" in Rights and Constitutionalism 177.

77 Dugard "International Human Rights" in Rights and Constitutionalism 177-178.

78 Currently, the monitoring mechanism of the CRC is that of reporting, combined with the provision of technical advice and assistance. See Verheyde and Goedertier A Commentary on the United Nations Convention on the Rights of the Child: Articles 43-45 The UN Committee on the Rights of the Child (2006) 15 par 14.

79 The first of these reports are due within two years of a state ratifying or acceding to the Convention, and thereafter every five years. See art 44(1) of the CRC; Verheyde and Goedertier A Commentary on the United Nations Convention on the Rights of the Child 15 par 16.

80 The Committee was established in 1985 by a decision of ECOSOC to merely "assist" in the "consideration" of state reports. Thus, the Committee is not a body established by treaty, but a subsidiary body of ECOSOC. It has the primary responsibility for "monitoring" the implementation of ESC rights protected under the ICESCR. The Committee is composed of 18 experts with recognized competence in the field of human rights, serving in their personal capacity, elected with due consideration given to equitable geographical distribution and to the representation of different forms of social and legal systems." See ECOSOC Decision 1985/17, par b; ECOSOC Res 1985/17, 28 May 1985 (in UN Doc E/1985/85, 15), par f; Report of the CESCR, UN Doc E/1999/22, par 24. 
any changes, information and exchange; and standard clarification and setting. ${ }^{81}$

In submitting their reports to the Committee, the states parties are to make their reports widely available to the public in their states and are further required to provide the Committee with sufficient information on how the Convention is being implemented within their territories. ${ }^{82}$ The report should include both factors and difficulties affecting the degree of fulfilment under the relevant Convention. The requirement that the states parties should include in their reports any difficulties which they have encountered in implementing the Convention's rights is designed to prevent such reports from becoming a thinly disguised public-relations exercise. ${ }^{83}$ It is expected that the reports should generate contributions to national debates on the prioritization of resources to combat such difficulties and measures necessary to overcome them, and also to indicate where technical advice and assistance is needed. ${ }^{84}$ In this context, states' reports provide a useful comparative gauge for measuring progress on the implementation of the Covenant's rights.

It is observed, however, that the periodic reporting system has particular weaknesses. ${ }^{86}$ In many cases, there is a back-log of reports; ${ }^{87}$ and the reports themselves often lack details. ${ }^{88}$ Many states' reports were given in an inadequate manner; they often do not properly follow the CESCR's guidelines regarding the form and contents of state reports. ${ }^{89}$ Since reports are always drawn up by national officials, they often try as much as possible to present their governments in a positive manner and conceal flagrant violations of human rights in their territories. In that context, those reports, in most cases, often lack objectivity and are therefore unreliable. ${ }^{90}$ Fundamentally, many states often fail to submit any reports with the

81 See Alston "The Purposes of Reporting", in United Nations Manual on Human Rights Reporting Under Six Major International Human Rights Instruments, UN Doc. HR/PUB/91/1 (1991) 13-16; and see also Odinkalu "Implementing Economic, Social and Cultural Rights Under the African Charter on Human and Peoples' Rights" in Evans and Murray African Charter on Human and People's Rights - The System in Practice, 1986-2000 (2002) 178 202.

${ }^{82}$ See art 44(6) of the CRC.

83 See Davel Introduction to Child Law in South Africa (2000) 211.

${ }^{84}$ Ibid.

85 Ibid.

86 See Kedzia "United Nations Mechanisms to Promote and Protect Human Rights" in Symonides (ed) Human Rights: International Protection, Monitoring and Enforcement (2003) 30.

87 In this regard, it was reported by the Office of the Human Rights Commissioner for Human Rights that as of January 2005, a total of 129 states' reports were overdue for the CRC. See Verheyde and Goedertier A Commentary on the United Nations Convention on the Rights of the Child 44 par 56; see also, Evans, Ige and Murray "The Reporting Mechanism of the African Charter on Human and Peoples' Rights" in African Charter on Human and People's Rights - The System in Practice, 1986-2002 38.

88 See Kedzia "United Nations Mechanisms to Promote and Protect Human Rights" in Human Rights: International Protection, Monitoring and Enforcement 30-37; and Olowu An Integrative Right-Based Approach to Human Development 35.

89 Beiter The Protection of the Right to Education by International Law (2006) 623.

90 See Verheyde and Goedertier A Commentary on the United Nations Convention on the Rights of the Child 46 par 56. 
Committee doing little or nothing to enforce compliance. ${ }^{91}$ Contrary to the guidelines, most reports do not indicate the difficulties affecting the implementation of the Covenant rights in their territories and therefore present little or no useful guidance to the CESCR. Also, many state reports are superficial and omit to include detailed descriptive and statistical information regarding the state of realization of Covenant rights to enable the CESCR to evaluate state performance under a particular instrument properly. ${ }^{92}$

In view of the above shortcoming, it is submitted that this mechanism of implementation is in need of an overhaul. ${ }^{93}$ It is therefore suggested that in submitting a state report on the right to education, the Ministry or the Department of Education needs to contribute in a meaningful way to the preparation of the state's reports. This should not be left to the Ministry or Department of Foreign Affairs which often co-ordinates the preparation of the state reports. For a state report to be complete, comprehensive and holistic in nature, it is important that the Non-State Actors (NSAs) and the Non-Governmental Organizations (NGOs) be afforded the opportunity of being actively involved in the preparation of reports. In addition, teachers' as well as students' unions should be involved in the preparation of state reports on education.

The importance of an adequate state report cannot be over-emphasized. As the Limburg Principles note:

"[T]he effectiveness of the supervisory machinery provided in Part IV of the Covenant depends largely upon the quality and timeliness of reports by States parties. Governments are therefore urged to make their reports as meaningful as possible. For this purpose they should develop adequate internal procedures for consultations with the competent government departments and agencies, compilation of relevant data, training staff, acquisition of background documentation, and consultation with relevant non-governmental and international institutions.

It is also recommended that the draft of such reports be made available for public discussions before the final report is submitted. The NSAs and NGOs should play an additional role by submitting independent "shadow reports" on the situation of the right to education in their territories. ${ }^{95}$ This will balance the possibility of any biased information presented on behalf of the states by government officials.

91 It is evident that many states treat the rules of international law with disdain and the occasional threats of collective economic sanctions and the use of force against a violating state have proved ineffectual. See Dugard "International Human Rights" in Rights and Constitutionalism 177; Mubangizi The Protection of Human Rights in South Africa: A Legal and Political Guide (2004) 14.

92 See generally, Coomans The International Protection of the Right to Education (1992) 213214; and Beiter The Protection of the Right to Education 623.

93 See Lundy "Schoolchildren and Health: The Role of International Human Rights Law" in Harris and Meredith (eds) Children, Education and Health: International Perspectives on Law and Policy (2005) 21.

94 Limburg Principles on the Implementation of the International Covenant on Economic, Social and Cultural Rights of 6 June 1986 (UN Doc. E/CN.4/1987/17, 1987) (1987) 9 Human Rights Quarterly 122 par 74.

95 Beiter The Protection of the Right to Education 624. 
The foregoing will enhance the effectiveness of the system and improve the quality of the content of state reports. Although from the available data it appears as if neither South Africa nor Nigeria has presented any state report on the state of education to the CESCR, the existence of such a mechanism will help the two countries in advancing their international obligations on the ICESCR. The state reporting-system, therefore, presents a valuable advantage to South Africa and Nigeria since states' reports and recommendations are often published. With the availability of the reports and recommendations thereon, both countries will have the opportunity of familiarizing themselves with common problems and utilize the appropriate solutions adopted by other states on educational issues. Apart from the states' reporting-system, another mechanism must be put in place, the rapporteur system, which will now also be examined.

\section{Special rapporteur system}

The practice of appointing Special Rapporteurs to explore the human-rights situation either in a particular state or pertaining to a particular theme has become a well-established feature of the United Nations human-rights machinery and ranks among its most innovative achievements. ${ }^{96}$ The rapporteur system is widely accepted as an important weapon in the arsenal of human-rights monitoring mechanisms. ${ }^{97}$ The system has also been adopted within other systems of human-rights protection, including the African regional mechanism. ${ }^{98}$ The United Nations has the power to appoint Special Rapporteurs to report on human-rights compliance within particular themes. It gives independent experts the opportunity to take multidisciplinary perspectives on a specific area of concern with individual countries. The UN Special Rapporteur on the Right to Education was first appointed in $1998,{ }^{99}$ and the Rapporteurs have made far-reaching findings on the realization of the right to education globally. ${ }^{100}$

96 Murray "The Special Rapporteurs in the African System" in Evans and Murray (eds) African Charter on Human and People's Rights - The System in Practice, 1986-2006 2ed (2008) 344.

97 See Lundy "Schoolchildren and Health: The Role of International Human Rights Law" in Children, Education and Health International Perspectives on Law and Policy 23.

98 Murray "The Special Rapporteurs in the African System" in African Charter on Human and People's Rights - The System in Practice, 1986-2006 344; see also, Evans and Murray "The Special Rapporteurs in African System" in Evans and Murray (eds) African Charter on Human and People's Rights - The System in Practice, 1986-2000 (2002) 280.

99 At the African regional level, a Special Rapporteur has not been appointed on the right to education, but such Rapporteurs have been appointed on extrajudicial execution; prisons and other conditions of detention; on women's rights in Africa; Refugees, Asylum Seekers and Internally Displaced Persons; and freedom of expression in Africa. See Mbelle "The Role of Non-Governmental Organisations and National Human Rights Institutions at the African Commission" in Evans and Murray (eds) African Charter on Human and People's Rights - The System in Practice, 1986-2006 289-315 302; Evans and Murray "The Special Rapporteurs in African System" in African Charter on Human and People's Rights - The System in Practice, 1986-2000 280.

100 See Tomasevski Economic, Social and Cultural Rights: The Right to Education, (Preliminary Report submitted by the Special Rapporteur of the Commission on Human Rights on the Right to Education) (1999), UN Doc. E/CN.4/1999/49; Tomasevski Economic, Social and Cultural Rights: The Right to Education, (Annual Report submitted by the Special Rapporteur of the Commission on Human Rights on the Right to Education) (1999), UN Doc. 
Notwithstanding its usefulness, the rapporteurs system is faced with a specific weakness and problem of lack of powers of investigation or enforcement, which hampers its efficacy. This weakness is recognized as a major obstacle on the Rapporteurs' duties. For instance, Katarina Tomasevski, the first Special Rapporteur on the Right to Education resigned her appointment citing her frustration at the obstacles and difficulties in carrying out her mandate. ${ }^{101}$ Thus, changes aiming at improving the quality of the states' reports as well as the administrative and specialist support available to the Rapporteurs have been advocated. ${ }^{102}$ Aside from this issue, it is acknowledged that the system ensures immediate, independent and in situ investigation on issues of specific concern, something which is not feasible within the states' periodic reporting procedure. ${ }^{103}$ The system is therefore an important mechanism towards realization of the right to education.

It should be noted that despite the several mechanisms put in place both at the international and national levels towards implementing the right to education, the realization of the right still remains elusive globally. The realization of the right to education is impeded by many factors or obstacles which the next section will now examine.

\section{OBSTACLES TO THE IMPLEMENTATION OF THE RIGHT TO EDUCATION}

It is observed that a number of factors impedes an effective implementation of the right to education in South Africa and Nigeria. This section focuses on those obstacles from a human-rights perspective. It identifies a number of factors that hinders the implementation of the right to education in terms of rights of individuals and obligations of duty-bearers. The right to education is a right with budgetary implication. It should therefore be noted that the economies of Africa countries are a major hindrance to the realization of the human rights with budgetary implications. ${ }^{104}$ More salient in this respect is the ineptitude and corruption of most governments' functionaries. ${ }^{105}$ Lack of transparency and accountability in the conduct of public affairs makes the realization of the socio-economic rights difficult to achieve in the sense that in most cases, money meant for public services is often embezzled or

E/CN.4/2004/45; Tomasevski Economic, Social and Cultural Rights: The Right to Education, UN Doc. E/CN.4/2000/6 (Progress Report submitted by the Special Rapporteur of the Commission on Human Rights on the Right to Education, 2000); Tomasevski Annual Report of the Special Rapporteur on the Right to Education (Annual Report 2001) 11 January 2001, E/CN.4/2001/52; Tomasevski "Has the Right to Education a Future within the United Nations? A Behind-the-Scenes Account by the Special Rapporteur on the Right to Education 1998-2004" 2005 5(2) Human Rights LR 205-237.

101 See Report of the Special Rapporteur on the Right to Education (Geneva: UN, 2004) E/CN.4/2004/45.

102 UN Secretary General, Strengthening of the United Nations: an agenda for further change (Geneva: UN, 2002) A/57/387 par 56-57.

103 See Lundy "Schoolchildren and Health: The Role of International Human Rights Law" in Children, Education and Health 23.

104 Mugawanya Human Rights in Africa: Enhancing Human Rights Through the African Regional Human Rights System (2003) 209.

105 Mugawanya Human Rights in Africa 209-210. 
diverted into private purses. ${ }^{106}$ These obstacles are multifaceted and interrelated and they are considered below.

\section{Financial obstacles}

Given the nature of the right to education, finance constitutes a major obstacle to the implementation or realization of this right in South Africa and Nigeria, as it does in every other developing country. Most governments use insufficient resources as an excuse to justify their inability to make all forms of education available and accessible to all. ${ }^{107}$ Lack of economic growth, an economic recession, lagging tax revenues and choices made in macroeconomic policies often leave countries with insufficient resources to invest in education. ${ }^{108}$ Finance presents itself as a militating factor from two angles: first, lack of resources available to the government to comply with obligations of providing education for all. ${ }^{109}$ The second angle concerns the existence of school fees as an economic and financial barrier for parents to have their children enrolled in school. ${ }^{110}$ The cost of education is a major reason why most parents keep their children and wards away from school and for children to drop out of school. However, these two aspects intersect because the need to charge school fees is always attributed to lack of government resources to finance education. ${ }^{11}$

Acknowledging that resources are a crucial factor in the implementation of the right to education, the ICESCR gives states the leeway to implement this right progressively. However, "progressive realization" should not be interpreted to imply that a state has that latitude to defer indefinitely its efforts to ensure full realization of the right to education. ${ }^{112}$ It should be emphasized that the concept of progressive realization does not mean an indefinite postponement of the states' obligations to implement; rather, it entails a number of basic and immediate commitments. ${ }^{113}$ As earlier submitted, even where the available resources are inadequate, the obligation remains on a state party to ensure the widest possible enjoyment of the relevant rights under the circumstances. ${ }^{114}$

106 See Registered Trustees of the Socio-Economic Rights \& Accountability Project (SERAP) v Federal Republic of Nigeria \& Universal Basic Education Commission (Suit No: ECW/CCJ/App/12/07; Judgement No: ECW/CCJ/JUD/07/10, delivered at Abuja, Nigeria on 30/11/2010) par 16, 18 and 19.

107 Coomans "Content and Scope of the Right to Education as a Human Right and Obstacles to Its Realisation" in Donders and Volodin (eds) Human Rights in Education, Science and Culture (Legal Developments and Challenges) (2007) 209.

108 Ibid.

109 Ibid.

110 Ibid.

111 Ibid.

112 See Maastricht Guidelines on Violations of Economic, Social and Cultural Rights (UN Doc. E/C.12/2000/13/2000) Guideline 21.

${ }^{113}$ Rishmawi A Commentary on the United Nations Convention on the Rights of the Child 33; see also, Lundy "Schoolchildren and Health: The Role of International Human Rights Law" in Children, Education and Health 14 and 15.

114 See CRC Committee, Concluding Observations: Jamaica (UN Doc CRC/C/15/ Add. 210, 2003) par 8, 17 and 18. 
However, it is important to distinguish between the inabilities of a state to comply with its obligations and its unwillingness to do so. A state which is unwilling to use the maximum of its available resources for the realization of a certain right is in violation of its obligations towards the realization of that right. ${ }^{115}$ On the other hand, if resources constraints render it impossible for a state to comply fully with its obligations, the state still has the burden of justifying that every effort has been made to use all available resources at its disposal in order to satisfy, as a matter of priority, the obligations under the Covenant. ${ }^{116}$ The development of jurisprudence on economic, social and cultural rights reflects that progressive realization does not allow for regression, stand-still, or indefinite postponement of implementation. ${ }^{117}$ Although South Africa has one of the highest rates of government investment in education in the world, ${ }^{118}$ the system of charging school fees negates the country's commitment to remove every obstacle on the right to education. Elimination of tuition fees and other user-fees systems in South African public schools will facilitate the realization of the constitutionally mandated goals, and guarantees access to education for all. ${ }^{119}$

In Nigeria, despite the policy of universal, compulsory and free basic education, many children do not have the opportunity of attending schools. The number of out-of-school children in Nigeria is estimated at around seven million. ${ }^{120}$ Finance, especially in the poverty-ridden communities, accounts for a large number of out-of-school children. In terms of the UBE Act, the government is obliged to provide free and compulsory basic education for every Nigerian of school-going age. ${ }^{121}$ Despite the government policy of free education, many schools still charge hidden fees such as registration fees and fees for use of computers which most parents cannot afford, resulting in children being kept away from schools. Although, there is no accurate data on public expenditure on education in Nigeria, the available materials indicate that funding of education is relatively low. It is noted that between 1999 and 2007, the Federal Government spent about N782.6 billion on

115 See General Comment 14 on the Right to the Highest Attainable Standard of Health (contained in UN Doc. HRI/GEN/1/Rev.7, 2000) par 47.

116 lbid.

117 Rishmawi A Commentary on the United Nations Convention on the Rights of the Child 33.

118 See the 2006/07 South African Yearbook 195; South Africa has one of the highest rates of government investment in education in the world. It allocated the sum of R122.8 billion to education in its in 2008/09 budget. See http://www.info.gov.za/aboutsa/education.htm (accessed 2009-08-26); the 2008 budget also allocated R121.1 billion to education. See Tucker "Every Child in School, Every Day" Education Law Project (Centre for Applied Legal Studies, Johannesburg): http://www.law.wits.ac.za/cals (accessed on 2008-09-15); see also, OECD Reviews of National Policies for Education: South Africa (2008) 24, which puts South Africa education spending at over $5 \%$ of Gross Domestic Product (GDP); and UNESCO puts the South Africa GDP at 5.4 percent. See UNESCO Global Education Digest 2009: Comparing Education Statistics across the World (2009) 176.

119 Woolman and Fleisch The Constitution in the Classroom: Law and Education in South Africa 1994-2008 (2009) 217-218.

120 See DFID Document on Education in Nigeria http://www.dfid.gov.uk/document/publications/ PSA/E_Nigeria.pdf (accessed 2009-08-08).

${ }^{121}$ S 2(1) of the UBE Act, 2004; see also, the UBEC The Compulsory, Free, Universal Basic Education 28. 
education. ${ }^{122}$ Nonetheless, this amount is relatively insufficient to cater for the needs in the Nigerian education sector.

\section{Poverty}

Another militating factor relating to that considered above is poverty. While financial obstacles relate to government resources, the issue of poverty essentially applies to parents and guardians. Poverty is described as the inability to acquire the essential material means to maintain life. ${ }^{123}$ Describing the ambit of poverty, Fleisch asserts: "poor adults tend to be caught in chronic unemployment and underemployment and, if working, employed in low-paid jobs. Poor people tend to have few household goods, regularly go hungry, and have inadequate housing and limited access to education and health care."124 In this sense, it is submitted that poverty is a common occurrence for many South Africans, particularly those living in rural areas. ${ }^{125}$ While state grants, particularly the old-age pension and the childsupport grant do provide income to poor families, it is observed that the low family income is still predominantly the consequence of limited formal employment. ${ }^{126}$

South Africa is classified internationally as a middle-income country with large numbers of the people living below the international poverty line. ${ }^{127}$ It is observed that currently about 35 percent of the population are vulnerable to food insecurity, ${ }^{128}$ while the country has an unemployment rate of over 26 percent. ${ }^{129}$ Recognizing this, the South African Constitutional Court once expressed thus:

"We live in a society in which there are great disparities in wealth. Millions of people are living in deplorable conditions and in great poverty. There is a high level of unemployment, inadequate social security, and many do not have access to clean water or to adequate health services. These conditions already existed when the Constitution was adopted and a commitment to address them, and to transform our society into one in which there will be human dignity, freedom and equality, lies at the heart of our new constitutional order. For as long as these conditions continue to exist that aspiration will have a hollow ring."

122 The breakdown is as follows: N30.6 billion in 1999; N64.2 billion (2000); N74.9 billion (2001); N45.5 billion (2002); N63.5 billion (2003); N90.3 billion (2004); N106.7 billion (2005); N151.7 billion (2006), and N205.2 billion in 2007. See Nigerian Tribune "FG Spends N782.6bn on Education in 9 Yrs - Minister" http://www.tribune.com.ng/12092008/news/ news10.html (accessed on 2008-09-12).

123 Barbarin and Richter Mandela's Children: Growing up in Post-Apartheid South Africa (2001) 173-174.

124 Fleisch Primary Education in Crisis: Why South African Schoolchildren Underachieve in Reading and Mathematics (2008) 55.

125 Fleisch Primary Education in Crisis 55-60; see also, Rose and Charlton "Prevalence of household food poverty in South Africa: Results from a large, nationally representative survey" 2002 5(3) Public Health Nutrition 383-389.

126 Fleisch Primary Education in Crisis 55.

127 Bilchitz Poverty and Fundamental Rights: The Justification and Enforcement of SocioEconomic Rights (2007) 245.

128 Ibid.

129 Bilchitz Poverty and Fundamental Rights 247.

130 Soobramoney v Minister of Health, KwaZulu-Natal supra, Chaskalson P par [8]. 
Poverty is prevalent in Nigeria and it has a negative impact on education. For example, as a result of poverty parents may not have money to buy standard textbooks, and may be unable to bear other costs associated with going to school. Poverty contributes to school failure; it sets in motion a chain of events that together create intractable impediments in the way of school achievement. ${ }^{13}$ There is a link between poverty and school performance, and on average, middle-class children do substantially better than poor children. This difference is primarily due to the manifold effects of poverty. ${ }^{132}$ There is a strong correlation between socio-economic background of a learner and academic performance; this is so because a learner's social and economic family characteristics are a powerful influence on his or her relative average achievement. ${ }^{133}$ Data shows that the average scores of disadvantaged school children are consistently below that of middle-class learners. ${ }^{134}$ This, however, does not rule out some exceptional cases where some disadvantaged children from under-sourced schools perform well in schools despite all obstacles.

The undeniable fact is that poverty is linked to under-achievement. For instance, children that are not adequately fed are likely to have difficulty concentrating in class or performing complex academic tasks. ${ }^{135} \mathrm{~A}$ survey by the Nelson Mandela Children's Fund's study on rural education reveals the link between poverty and academic performance. The study found that 14 percent of all children surveyed reported having either tea or nothing as breakfast, and 75 percent reported having tea with bread or porridge. Teachers' testimonies from those rural schools provide powerful evidence that links poverty to under-achievement. One teacher describes the experience of her learners thus: "[t]hey come without food and they eat here at school ... Sometimes they come inadequately dressed, without a jersey or shoes and it is cold and it's a learner who does not have a home. When a child is shivering, he doesn't learn well. That's the reason he has a difficulty. He won't listen to you or concentrate on what you do because of hunger and cold that he is feeling." 136 Further, while lack of money to enrol at school affects education, irregular income equally has an impact on regular school attendance which is likely to affect children's learning. ${ }^{37}$

\section{Health-related problems}

Health of the students or pupils is another important factor influencing the realization of the right to education. The relationship between the right to education and the right to health also exemplifies the indivisibility and

131 See Fleisch Primary Education in Crisis 53.

132 Ibid.

${ }^{133}$ See Rothstein Class and Schools: Using Social, Economic and Educational Reform to Close the Black-White Achievement Gap (2004) 16.

${ }_{134}$ See Fleisch Primary Education in Crisis 52-53.

135 Studies have shown that the effects on children that skip breakfast include poor learning. See Sibanda-Mulder "Nutrition and School Performance" September 2003 Annual ECOWAS Nutrition Forum 11.

136 See Nelson Mandela Foundation Emerging Voices: A Report on Education in South African Rural Communities (2005) 54; and see also Fleisch Primary Education in Crisis 36.

${ }^{137}$ Fleisch Primary Education in Crisis 67. 
interdependence of all human rights. ${ }^{138}$ As explained above, there is a link between poverty, food intake and school performance. Poverty impacts on learning through chronic and acute ill-health, in the same vein, undernutrition is also associated with poor cognitive function, late enrolment and frequent illness. ${ }^{139}$ Thus, undernutrition (as a result of poverty) is associated with the delay of cognitive development and ultimately poor school achievement. ${ }^{10}$ Apart from poverty-induced sickness, other health problems that have an impact on education include parasite infection, hearing loss, asthma, fatal alcohol syndrome, malaria and HIV/AIDS. ${ }^{141}$ Because of their prevalence and the huge negative impact on the right to education, only the last two diseases, HIV/AIDS and malaria will be examined.

Malaria has a significant effect on learning achievement. Although the incidence of malaria poses little or no threat to the South Africa learners, ${ }^{142}$ this is not the case in Nigeria where malaria is a common sickness in view of the country's hot weather. It is noted that malaria accounts for three out of every 10 childhood deaths in Nigeria, and more precisely, a child in Nigeria dies of malaria every 30 minutes. ${ }^{143}$ This death rate is too high and, therefore, unacceptable. ${ }^{144}$ It is pointed out that on the African continent as a whole, malaria accounts for one in five childhood deaths. ${ }^{15}$ In addition to high mortality levels, the high prevalence of malaria transmission in children means that a significant portion of school-goers suffer long-term damage of malaria in the form of epilepsy, neurological damage, and health problems that compromise children's normal development and inevitably affects school achievement. ${ }^{146}$ Also, repeated episodes of malaria lead to severe anaemia, which is equally linked to delayed intellectual development. ${ }^{147}$ Death and disability associated with malaria reduce family resilience to economic shock and, in the long term, children that get malaria will miss school and more frequently and ultimately underachieve.

Regarding HIV/Aids, it is noted that the impact of the pandemic on education systems is catastrophic in South Africa. ${ }^{149}$ South Africa is

${ }^{138}$ See Lundy "Schoolchildren and Health: The Role of International Human Rights Law" in Children, Education and Health 3.

139 See Kloka "Nutrition of school-aged children" Paper presented at the Colloquium on Improving the Health of School-aged Children in an Era of HIV/Aids - Linking Policies, Programmes, and Strategies for the $21^{\text {st }}$ Century (2003) 15.

140 See Fleisch Primary Education in Crisis 34.

141 Fleisch Primary Education in Crisis 32.

142 Fleisch Primary Education in Crisis 38.

143 Oguntola "Malaria, Deadly and can kill within Hours" quoting Taiwo Olarinde, an Assistant Manager, Global Fund Malaria Programmes, Society for Family Health (SFH), Ibadan, Nigeria. See Nigerian Tribune of 29 April 2010 http://www.nigeriamasterweb.com/ paperfrmes.html (accessed 2010-04-29).

144 See The Punch Newspaper of 25 April 2010.

${ }^{145}$ Fleisch Primary Education in Crisis 37-38; it is observed that about 850,000 persons die daily in sub-Saharan Africa due to malaria. See "US to cut Malaria Related Death by Half in Nigeria" The Punch Newspaper of 25 April 2010 http://www.nigeriamasterweb.com/ paperfrmes.html (accessed 2010-04-27).

${ }^{146}$ Fleisch Primary Education in Crisis 37.

147 Ibid.

${ }^{148}$ Fleisch Primary Education in Crisis 37-38.

149 Van Wyk "HIV/AIDS Policy in South African Schools" in Harris and Meredith (eds) Children, Education and Health: International Perspectives on Law and Policy (2005) 183-198 184; 
considered to have one of the highest HIV/Aids-prevalence rates in the world. ${ }^{150}$ It is estimated that around 12 percent of the almost 46 million South Africans have HIV. ${ }^{151}$ This translates into an estimation that between five and six million South Africans are infected. It is further estimated that 800 to 1,000 South Africans die of AIDS per day, which brings the total to approximately 300,000 people per year. ${ }^{152}$ Without anti-retroviral treatment, about 30 percent of the babies born to infected mothers are themselves infected. ${ }^{153}$ Thus, children infected with HIV will ultimately form part of the school population and learners may have to take time off to look after themselves or their family members who are infected or have to carry out household tasks for them. ${ }^{154}$ In this regard, the pandemic impacts negatively on the education system. Also, HIV/Aids accounts for decline in demand for schooling; it also reduces educator numbers with resultant affects on the quality of education; it creates trauma in the classroom and increasingly embattles school-leadership corps. ${ }^{155}$ It also reduces the number of parents with resultant increase in orphans living in deepening poverty, which impacts negatively on school-enrolment rates. ${ }^{156}$

\section{Discrimination, socio-economic and cultural obstacles}

Active discrimination in education may occur through intentional acts or failures to act by government authorities or private persons, leading to a discriminatory situation in terms of article 1(1) of the UNESCO Convention against Discrimination in Education. The essential characteristic of this provision is that discrimination in education leads to an exclusion of people based on certain grounds that obstruct equality of treatment. There are also situations of systemic forms of discrimination in education as a result of more or less structural patterns in society due to financial, social, economic, cultural, historical or geographical reasons. ${ }^{157}$ Traditions, customs and social norms and practices within societies and families also impact on the right to

Coombe "Keeping the Education System Healthy: Managing the Impact of HIV/Aids on Education in South Africa" 2000 3(1) Current Issues in Comparative Education 1-13; Fleisch Primary Education in Crisis 37-38; and Barry Schools and the Law: A Participant's Guide (2006) 153.

150 Brand Financial Constitutional Law: A Comparison Between Germany and South Africa (2006) 301; Department of Health National HIV and Syphilis Antenatal Zero-Prevalence Survey in South Africa: 2002 (2003) 6 and 11.

151 See Van Wyk "HIV/AIDS Policy in South African Schools" in Children, Education and Health 184 and 185

152 National HIV and Syphilis Antenatal Zero-Prevalence Survey 12; and see also Dorrington, Bradshaw and Budlender HIV/AIDS Profile in the Provinces of South Africa: Indicator for 2002 (2002) 4-5.

153 National HIV and Syphilis Antenatal Zero-Prevalence Survey 11.

154 See Van Wyk "HIVIAIDS Policy in South African Schools" in Children, Education and Health 185.

155 Fleisch Primary Education in Crisis 37-38; Barry Schools and the Law 153;and Van Wyk "HIV/AIDS Policy in South African Schools" in Children, Education and Health 185.

156 Coombe 2000 3(1) Current Issues in Comparative Education 1-13; and see also Fleisch Primary Education in Crisis 37-38 and 45.

157 Coomans "Content and Scope of the Right to Education as a Human Right and Obstacles to Its Realisation" in Human Rights in Education, Science and Culture 214. 
education. In many African societies, the notion that boys are productive and should be valued is still rampant, while girls are often downgraded. These views about the perceived roles of girls and boys to a large extent often determine who among the children of a family are sent to school. ${ }^{158}$

The effect of this customary and cultural perception is the issue of gender discrimination in terms of education, as is often reflected in the enrolment disparity between boys and girls. Gender parity is a quantitative concept which refers to the equal enrolment and participation of both girls and boys in different levels of education. Gender equality on the other hand is a qualitative concept; it refers to equal educational outcomes for boys and girls. ${ }^{159}$ While gender disparity is not seen as a problem in the South African education sector, it is a problem in Nigeria. Available data shows that there is still a high disparity in the male and female school-enrolment rate especially in Northern Nigeria, which impacts negatively on the right of a girlchild to education. ${ }^{160}$ Inequalities and gender discrimination within a family also affect girls' education. In many cases, as the family gets poorer, preference is given to boys in attending schools while girls are denied education. ${ }^{161}$ This impedes the realization of the right to education.

Also, some forms of overt discrimination such as the practice of suspending pregnant girls from school, constitute obstacles to the realization of the right to education. The South African legal framework fares well in this respect by prohibiting the suspension of a learner from school on account of pregnancy. Conversely in Nigeria, schools may suspend a pregnant learner from schools as a form of disciplinary measure. This practice is capable of impacting negatively on the right of a girlchild to education. The measure put in place in the Child's Rights Act that a female child who becomes pregnant before completing her education should be given the opportunity after delivery, to continue with her education should be strictly adhered to.

158 See generally Taiwo "Women Rights and Gender Equality in Nigeria: Socio-cultural Perspectives" 2009 2(1) Nigeria Journal of Public Law 67-76; and Taiwo "Customary Law Rule of Primogeniture and its Discriminatory Effects on Women's Inheritance Rights in Nigeria: A Call for Reform" 2008 22(2) Speculum Juris 104-122.

159 Coomans "Content and Scope of the Right to Education as a Human Right and Obstacles to Its Realisation" in Human Rights in Education, Science and Culture 215.

160 Statistics from the 2006 National Personnel Audit show that there are 54,434 public primary schools in Nigeria (while the 2006 School Census states 87,941 as the number of primary schools) with an enrolment figure of $24,422,918$ of which the males account for $13,302,269$ (or $54.5 \%$ ) while the females account for $11,120,649$ (or $45.5 \%$ ) indicating a gender parity of $83.6 \%$. More males are enrolled in the primary schools than females in the North while a near parity is recorded in the South. About $65 \%$ of primary school children in the North are male while $35 \%$ are female. There are also 7,129 public Junior Secondary Schools in Nigeria with a total enrolment figure of $3,266,780$. Gender disparity exists in male and female enrolment figures at the JSS level nationwide. About $55 \%$ are male while $45 \%$ are female. See Roadmap to Nigeria Education (2009) 19.

161 See Coomans "Content and Scope of the Right to Education as a Human Right and Obstacles to Its Realisation" in Human Rights in Education, Science and Culture 216.

162 See s 15(5) of the Child's Rights Act, Cap C50, Laws of the Federation, 2004 (Nigeria). 


\section{Socio-political obstacles}

An important obstacle to the realization of the right to education is also of a political nature coupled with the problem of resource mobilization. The recent Nigerian policy paper on education acknowledges low political will and low commitment as important obstacles to the right to education. ${ }^{163}$ Implementing the right to education presupposes the recognition of other concomitant rights that are politically sensitive, such as linguistic freedom and educational rights of the minorities and the recognition of cultural identity of indigenous groups. ${ }^{164}$ Other issues are the choices and priorities in government spending. The experience in Nigeria is that the education sector receives one of the lowest government's budgetary allocations with military and defences receiving the highest budgetary allocations. This arrangement has consistently elicited protests and strikes in the Nigerian education sector, especially at the tertiary level.

Another obstacle of a political nature that has a devastating impact on the realization of the right to education is the consistent communal conflicts or crises as well as post-election violence experienced in Nigeria. Examples in this regard in the recent time are the Niger Delta and Jos crises, Bauchi and Maiduguri crises among others which left many people dead with millions dollars' worth of properties destroyed. Schools buildings and facilities were destroyed and children were unable to go to schools as long as the crises lasted. Further, pupils are the victims of a communal crisis and the resultant traumas may negatively affect their school performances. The fact that many teachers and parents were killed, with several school buildings destroyed, makes the period of educational recovery after the end of conflicts a very difficult one. Also, corporal punishment and bullying are barriers to learning with the impact of raising the number of pupils who drop out of school. Such practices are contrary to a safe school environment and impact negatively on the right to education. ${ }^{16}$

\section{Obstacles relating to the quality of education}

To make education acceptable for pupils and adapted to their needs, it is essential that the quality of education be good. ${ }^{166}$ However, educational institutions, teachers and children face a number of obstacles in this respect. Obstacles impeding quality of education include poor school buildings, facilities and lack of adequate personnel resulting in a poor pupil-teacher ratio. ${ }^{167}$ Another problem impacting on quality of education is teacher absenteeism, which in most cases is a symptom of poor or low teachers' salaries which forces many teachers to have an additional job. ${ }^{168}$ School

163 See Roadmap to Nigeria Education 35.

164 See Coomans "Content and Scope of the Right to Education as a Human Right and Obstacles to Its Realisation" in Human Rights in Education, Science and Culture 219.

165 See Committee on the Rights of the Child "General Comment No. 1 on Article 29(1): The Aims of Education" (UN Doc. CRC/GC/2001/1) par 19.

166 Coomans "Content and Scope of the Right to Education as a Human Right and Obstacles to Its Realisation" in Human Rights in Education, Science and Culture 219.

167 Ibid.

168 lbid. 
environment is also very crucial: inadequate facilities such as poor buildings, lack of furniture, inadequate sanitation, and lack of teaching materials seriously hamper a child's ability to concentrate and learn. ${ }^{169}$ This problem impacts negatively on the realization of the right to education in both South Africa and Nigeria.

In Nigeria, it is observed that many schools lack the essential infrastructure to enable them to function as safe, efficient and effective schools. It is observed that the vast majority of schools both in urban or rural areas have no water, sanitation and electricity. The physical state of classrooms is very poor, with floors full of holes, roofs and ceilings broken, and overall, the fabric is in a poor state of repair. ${ }^{170}$ Windows have shutters at best but these and doors are often not lockable, leaving most schools without security. Few Nigerian schools have a perimeter fence or enclosure, again making them open to intruders and vandalism. In some circumstances furniture is stolen and classrooms are used as toilets. ${ }^{171}$ Equally in South Africa, it is observed that most schools especially in rural areas, lack the resources to provide learners with the education they need to participate effectively in society. ${ }^{172}$ Also, pupil-to-teacher ratios in most rural schools are as high as 51 to 1 , while many school buildings are in a poor condition needing repairs. ${ }^{173}$ It is further noted that most schools do not have safe drinking water within the walking distance, have no toilets nor telephones and are badly overcrowded. ${ }^{174}$

\section{Legal status or classification of the right to education}

Another condition impeding the realization of human rights is the legal status or classification of such rights. ${ }^{175}$ The most obvious bar to the judicial protection of socio-economic rights is the non-inclusion of such rights in the constitution, or their inclusion in the form of non-justiciable directive principles of state policies. ${ }^{176}$ The Nigerian Constitution is one of the many constitutions in the modern time that follow the classification of rights into fundamental rights on the one hand and the directive principles of the state policy on the other. ${ }^{177}$ The Constitution recognizes two sets of "rights", namely the fundamental human rights and fundamental objectives and directive principles of state policy. ${ }^{178}$ There is a significant difference

169 Ibid.

70 Roadmap to Nigeria Education 26.

171 lbid.

172 Berger "The Right to Education under the South African Constitution" 2003103 Columbia LR 614-661 and 619-620.

173 Berger 2003103 Columbia LR 619.

174 Berger 2003103 Columbia LR 619-620.

175 Ray and Tarrow "Human Rights and Education: An Overview" in Tarrow (ed) Human Rights and Education (1987) 312.

176 See Viljoen "The Justiciability of Socio-economic and cultural Rights: Experience and Problems" in Human Rights in Education, Science and Culture 90.

177 Chap IV of the 1999 Nigerian Constitution contains the fundamental human rights while Chap II contains the fundamental objective and directive of the state policy.

178 S 13-24 deal with objective policy while s 33-46 contained fundamental rights. 
between the two sets of rights as provided for in the Nigerian Constitution. While fundamental rights are justiciable, the "rights" which classify fundamental objectives and directive principles, which include the right to education, are non-justiciable. ${ }^{179}$

In a nutshell, non-justiciability entails the inability of the courts to avail themselves of litigant judicial remedies or relief in view of the inappropriateness of the judicial process in resolving the dispute, which ordinarily should be channelled to another organ of state with requisite competence to deal with the problem. ${ }^{180}$ Owing to their non-justiciability, the value of the directive principles is that they place moral and political, rather than legal, obligations on the state. ${ }^{18}$

Conversely, the right to education is provided for as a justiciable right under the 1996 South African Constitution. Given the inclusion of socioeconomic rights as enforceable rights in its provisions, the South African Constitution presents itself as a model in terms of enforcement of socioeconomic rights in Africa. ${ }^{182}$ In many of the cases on this issue, government actions, policies and laws denying or impeding the enjoyment of socioeconomic rights have been successfully challenged, and courts have consistently held that these rights are enforceable under the Constitution. ${ }^{183}$ Although there are positive developments as far as the domestic justiciability of the right to education is concerned, the legal culture in Nigeria classifying it under the directive principles is still a serious obstacle.

The article reveals that, despite the wide recognition of the right to education in the various human rights instruments, the realization of this right remains elusive in South Africa and Nigeria due to the factors identified above. This article will in the next section make some suggestions on how to address the problems. It is hoped that if these suggestions and recommendations are followed, they will go some way to ensure a better realization of the right to education in South Africa and Nigeria.

179 See s 6(6)(c) of the 1999 Nigerian Constitution which provides that the judicial powers vested (by the Constitution) in the courts: "shall not extend ... to any issue or question as to whether any act or omission by any authority or person or as to whether any law or any judicial decision is in conformity with the fundamental objectives and directive principles of state policy set out in Chapter II of the Constitution". See also Uzoukwu v Ezeonu II supra 761-762; Agbede "The Rule of Law and the Preservation of Individual Rights" in Ajomo and Owasanoye (eds) Individual Rights Under the 1989 Constitution (1993) 35; Aguda "Judicial Attitude to Individual Rights in Nigeria" in Ajomo and Owasanoye (eds) Individual Rights under the 1989 Constitution (1993) 68; Aguda The Judiciary in the Government of Nigeria (1983) 77-78; and Olowu 2006 69(1) Saskatchewan LR 56.

180 Okpaluba "Justiciability, Constitutional Adjudication and the Political Question in a Nascent Democracy: South Africa (Part 1)" 200318 SAPR/PL 331332.

181 De Villiers "Social and Economic Rights" in Van Wyk, Dugard, De Villiers and Davis (eds) Rights and Constitutionalism: The New South African Legal Order (1994) 615.

182 South African Constitution's socioeconomic rights' provisions have been celebrated internationally. See Kende Constitutional Rights in Two Worlds 244-245.

183 See Soobramoney v Minister of Health, KwaZulu-Natal supra; 1997 (12) BCLR 1696; Government of the Republic of South Africa $v$ Grootboom supra; Minister of Health $v$ Treatment Action Campaign (No 2) 2002 (5) SA 721 (CC); Bel Porto School Governing Body $v$ Premier of the Province, Western Cape 2002 (9) BCLR 891 (CC); Christian Education South Africa v Minister of Education 2000 (4) SA 757 (CC); and Khosa v Minister of Social development supra. 


\section{SUGGESTIONS AND RECOMMENDATIONS}

This article has argued that despite the recognition of the right to education in the various global, regional and national human-rights instruments, the actualization of this right remains elusive due to the factors identified above. The pertinent issue in this section, therefore, is to address those steps/measures that need to be taken to improve on the right to education in the light of the problems identified. This section will address those issues with the aim of proffering some suggestions/recommendations on how to implement the right to education effectively in the two countries. It will advocate for a better realisation of the right to education. In the light of those problems, the following recommendations become imperative:

\section{The Governments should make education available and accessible to all without discrimination}

First, it is recommended that both the South African and Nigerian governments should ensure that education is available and accessible to all without discrimination. Given that deprivation of education is difficult (and often impossible) to redress subsequently in life, governments should identify the barriers the disadvantaged groups such as girls, street children and the disabled face and prioritize attention and funding on the rights of these groups so as to eliminate those barriers. This recommendation is fundamental with the view to the Millenium Development Goals achieving universal education for all without discrimination by the year 2015. To ensure gender parity, especially in Nigeria, government and policy-makers should introduce programmes targeting girls' education and other neglected groups of people in society.

In addition, the status of girls and women within society as a whole is an issue that needs to be addressed. As earlier pointed out, traditional and cultural perceptions on the roles of female children in society often lead to enrolment disparity between boys and girls and this should be addressed. The following specific strategies will help girls gain a basic education: schools should be located closer to communities with safer learning environments; recruitment of more female teachers to serve as role models for female learners; and development of gender-relevant curricula by introducing topics that are of interest to girls and that coincide with their aspirations. Also, the practices such as the early marriage of girls are important causal factors for girls' drop-out from school, especially in northern Nigeria. In this context, the Nigerian government needs to enforce the provision of the Child's Rights Act prohibiting child marriage vigorously.

\section{Improved financial commitments and provision of adequate resources}

Given that the main obstacle to access and enjoyment of the right to education in the world over is finance, the South African and Nigerian governments should accord much more financial commitment to their education sectors. They should strengthen national and international efforts 
to increase available resources, monitor budgets and spread allocation of resources in an equitable manner. This is achievable by increasing the total annual budgetary allocation to educational institutions, education ministries and departments. Both governments should ensure that all children enjoy their right to free education and that no child should be denied the right to education on account of school fees or related costs. Strategies and policies aiming at eliminating or reducing the costs of attending school, such as total abolition of tuition and other incidental fees, should be put in place.

It should be borne in mind that while basic education is supposed to be free in the public sector in view of the governments' "no-school-fees" policy and the UBE programme in the two countries, parents are still responsible for many other direct and indirect costs on items including textbooks, uniforms, transport and other levies. In view of widespread poverty in South Africa and Nigeria, these fees have become one of the main causes of low school enrolments in Nigeria in particular, and low school attendance in the two countries. To this end, a system of providing stipends, bursaries, scholarships, and free text books for learners is hereby recommended to both countries. Though this recommendation has some financial implications on the governments in both countries, given that deprivation of education is always difficult to redress in later life, both countries should do their utmost in this regard.

\section{Improving the quality of schools' facilities and infrastructure}

The quality of education is an important factor in regard to the implementation of the right to education in any country. The school is the institutional and physical setting for education. The quality of school facilities seems to have a direct and an indirect effect on learning as well as on learners' physical and psychological growth, an effect that is difficult to measure. A key issue, therefore, is whether the number and location of schools and classrooms match the school-age population and its distribution and whether the construction of school infrastructure is sufficient to keep pace with the growth of the school-age population. A related issue is whether the physical condition of school buildings is conducive to creating a favourable learning environment. As pointed out above, obstacles impeding quality of education include poor school buildings, facilities and lack of adequate personnel, resulting in poor pupil-teacher ratio. A clean water supply, classrooms maintenance, space and furniture availability all have an impact on the critical learning, learning output and quality of education.

The physical quality of schools always has a potentially depressing effect on enrolment and attendance, particularly in the case of girls, and even presents a more negative effect on the quality of the learning experience. Location of schools and facilities in those schools are major considerations which many parents consider before sending their children to school. It is therefore important that governments should endeavour to make school environments conducive for learning by constantly improving the school facilities. Also, governments should help by providing assistance in the production of appropriate low-cost learning materials in order that each child 
would be guaranteed a packet of basic learning materials, including textbooks, exercise books and other writing materials. Governments should also ensure that there are standard laboratories, computer and internet facilities as well as well-equipped libraries in schools at all levels.

\section{Improving the quality of teachers and their conditions of service}

The number, quality and motivation of teachers have major consequences both for school enrolment, school attendance and learners' achievement. Therefore, an important index of quality of education is the teacher factor. Inadequate numbers of teachers are one of the likely causes of low educational standards. For quality education, there should be an appropriate and a low pupil-teacher ratio at all levels of education, particularly at the primary and secondary levels. In primary, secondary and tertiary education sectors, the low rating of the teaching profession has a profound effect on teachers' quality and motivation for work. In Nigeria in particular, it is observed that due to government neglect and poor working conditions, many qualified teachers are consistently migrating to the developed countries in Europe, America as well as other African countries.

In Nigeria, teachers are poorly motivated and their salaries and emoluments are pitifully inadequate. This impacts negatively on the quality of education since the teacher absenteeism in most cases is the result of poor or low teachers' salaries which force many teachers to have an additional job. Revitalization of basic education should begin with improvements in the quality and lives of those engaged in education. It is therefore recommended in light of the foregoing that governments in both countries should, as a matter of necessity, review the teachers' emoluments periodically in order to serve as incentive to them and make them more committed to their work.

\section{Making the right to education a justiciable right}

This recommendation is particularly relevant to Nigeria in the sense that South Africa has incorporated as justiciable rights a comprehensive range of justiciable economic, social and cultural rights, including the right to education, in its Bill of Rights. ${ }^{184}$ Under the Nigerian Constitution, the right to education is classified under the directive principles of the state policy. The legal classification of the right to education, to some extent, affects its realization. ${ }^{185}$ It is recommended that the Nigerian government ratify all the

184 See s 23, 24, 25, 26, 27, 29, 30, 31 and 35(2)(e) of the 1996 South African Constitution.

185 See in this regard, the Centre on Housing Rights and Eviction (COHRE)'s 2004 Report on Housing Rights in West Africa which summarized the Centre's assessment of the constitutional status of economic, social and cultural rights as well as institutional attitudes to and policy impact of their implementation in Nigeria in three main areas thus: "[f]irst, the legal enforcement of constitutionally recognized economic and social rights in Nigeria is difficult. Second, the courts are, at best, reluctant to entertain complaints based on these rights. Third, Nigeria lacks the bureaucratic and institutional capacities to implement these rights." Centre on Housing Rights and Eviction (COHRE) Housing Rights in West Africa: Reports of Four Fact-Finding Missions (2004) 21. 
relevant international human-rights instruments on socio-economic and cultural rights and make them a part of a national legal system as section 12 of the Nigerian Constitution stipulates. Government should also ensure their strong protection in its national legal systems, including recognizing them in the Constitution as justiciable rights. It should also provide avenues for redress by providing access to strong remedies at the national level once these rights are violated.

An underlying argument in this article is that economic, social and cultural rights are human rights that have a special role to play in the protection of democratic principles. It is pivotal that civil and political rights are themselves better protected when economic, social and cultural rights are accorded adequate recognition within domestic legal systems. ${ }^{186}$ Given that all human rights are interrelated, interdependent, and mutually supporting, one cannot promote ICCPR effectively without also protecting the ICESCR. While it is generally recognized that implementing socio-economic rights has more resource-related implications compared to civil and political rights, the South African constitutional experience has shown that people can claim socioeconomic rights from domestic courts without crippling the economy.

The Indian experience also demonstrates that directive principles may, in practice, become justiciable. Through judicial activism and expansive interpretation, the Indian judiciary has been able to put life into nonjusticiable rights in the Constitution. Nigeria, too, can afford to guarantee these rights in its Constitution without crippling the economy. It is submitted that CESCR would be acting in the proper direction if it begins to assert this and encourage state parties to the ICESCR to facilitate the consideration of economic, social and cultural rights in constitutional drafting and review processes. ${ }^{187}$ Thus, one important area where Nigeria could learn from South Africa is the issue of justiciability and constitutionalizing socioeconomic and cultural rights. The Nigerian government therefore needs to do more to give the right to education a constitutional status by entrenching it as a justiciable right in the Constitution.

\section{Seeking financial assistance and cooperation from international institutions}

Where a developing state party to the ICESCR considers that taking steps to realize core obligations in respect of socio-economic and cultural rights is beyond the maximum resources available to it, it is appropriate for such a state to seek international assistance in order to fulfil its core obligations. ${ }^{188}$ Given the level of poverty, the quality and progressive slide of education in South Africa and Nigeria, it would not be out of place for both countries to solicit international financial assistance and collaboration in the form of aid to solve their education problems. This recommendation is particularly relevant in view of the provisions of article 2(1) of the ICESCR which provides inter alia that "[e]ach State party to the present Covenant undertakes to take

\footnotetext{
186 See Olowu An Integrative Right-Based Approach to Human Development 9.

187 Olowu An Integrative Right-Based Approach to Human Development 98.

188 Ssenyonjo Economic, Social and Cultural Rights in International Law (2009) 81.
} 
steps, individually and through international assistance and co-operation, especially economic and technical, to the maximum of its available resources ..."189

A similar provision is contained in article $28(3)$ of the CRC which states: "States parties shall promote and encourage international cooperation in matters relating to education, in particular with a view to contributing to the elimination of ignorance and illiteracy throughout the world and facilitating access to scientific and technical knowledge and modern teaching methods. In this regard, particular account shall be taken of the needs of developing countries." 190 Of particular note are also the provisions of articles 55 and 56 of the UN Charter. Article 56 creates an obligation for all the UN member States to co-operate and collaborate, jointly and severally, with the UN for the achievement of the purposes set forth in article 55. Article 55(a) and (b), in turn, commits the UN to the promotion of "(a) higher standards of living, full employment, and conditions of economic and social progress and development; (b) solutions of international economic, social, health, and related problems; and international cultural and educational co-operation; ...,191

It is submitted that the obligation on international co-operation and assistance on education accrues to states as collective entities and richer countries are called upon to help in solving poorer nations' educational problems. ${ }^{192}$ Richer states are expected to transfer financial and technical resources and their know-how in an effort to reduce the gap between educational facilities in industrialized and developing countries. ${ }^{193}$ In this respect, the Limburg Principles state that international co-operation and assistance pursuant to the UN Charter and the ICESCR must accord priority to the realization of human rights, whether civil and political rights or economic, social and cultural rights. ${ }^{194}$ The expected international aid and cooperation should, therefore, be geared towards strengthening the educational system and policies in the developing countries.

\section{CONCLUSION}

This article has examined the implementation strategies put in place towards realizing the right to education in South Africa and Nigeria. It examined the relevant provisions of international, regional and national human-rights instruments on the right to education and comes to the conclusion that the right to education is well-established as it is widely ratified as a legally binding human right. The article argued that by having ratified international agreements in which the right to education is protected, international

\footnotetext{
189 Authors' own emphasis added.

90 Authors' own emphasis added.

191 Authors' own emphasis added. See also art 2(1) of the ICESCR; art 28(3) and (4) of the CRC; CRC Committee General Comment 5 par 63-64; Committee on Economic, Social and Cultural Rights (CESCR) General Comment No 13: the Right to Education (E/C.12/1999/10 of 8 December 1999) pa 60.

192 Beiter The Protection of the Right to Education 43.

193 Ibid.

194 Par 29 of the Limburg Principles.
} 
obligations and duties are imposed on both South Africa and Nigeria to make primary, secondary and higher education available, accessible, acceptable and adaptable in their territories. It pointed out, however, that despite these obligations and international commitments to provide education for all, there is a significant gap between what is stipulated and the practical realities in the two countries.

The conclusion drawn from the discussion in this article is that the implementation/realization of the right to education in both countries is unsatisfactory, and this is due to many militating factors identified in the article. Solving these problems and making the right to education realizable in both countries, therefore, call for a renewal of governmental commitments and investment of appropriate human and financial resources, as well as international co-operation to achieve the right to education for all in practice. It also requires concerted efforts on the part of the various actors in education, such as the governments at all levels, the human-rights monitoring bodies, inter-governmental bodies as well as the UN specialized agencies on education. 